\title{
Compliance with treatment in asthma and Munchausen syndrome by proxy
}

\author{
V Godding, M Kruth
}

\begin{abstract}
Among 1648 asthmatic patients, 17 families (1\%) were identified as having Munchausen syndrome by proxy. Ten families did not treat their children's, attacks or refused medical care, and seven exaggerated the severity of symptoms to obtain invasive investigations and treatment. All the families had disturbed psychosocial backgrounds. The abuse consisted mainly of neglect, in that necessary treatment was not given. In some cases a more direct form of abuse was observed, when useless and sometimes harmful investigations and treatment were given.

We conclude that medical control of the compliance of both parents and children is necessary in the management of childhood asthma.
\end{abstract}

Munchausen syndrome by proxy describes parental behaviour that creates the appearance of, or produces, physical illness in a child with harmful consequences to the child. It was first described by Meadow, ${ }^{12}$ and is now well documented. It may be relatively common, but is frequently unrecognised. ${ }^{134} \mathrm{It}$ usually takes the form of the mother falsifying an illness, and presenting the child for medical assessment and care, often resulting in numerous procedures. It has been recorded in several childhood disorders including infectious, renal, and neurological diseases ${ }^{5}$; haematological, endocrine, and gastrointestinal conditions; and allergies. ${ }^{6}$ It is difficult to diagnose and is often poorly identified and managed by health care professionals. $^{3}$

There is still controversy about what constitutes the diagnosis with opinions ranging from simple neglect to active attacks on the child's health, or life, or both. ${ }^{7}$ A recent approach suggested by Meadow is the concept of a range of types of Munchausen syndrome by proxy from perceived illness (symptoms perceived as illness by the mother) and trying one doctor after another, to enforced invalidism (the child is taught to become an invalid), and fabricated ill-

UCL University Hospital of Mont-Godinne, B-5530 Yvoir, Belgium Department of Paediatrics V Godding

Department of Child Psychiatry M Kruth

Correspondence to: Dr Godding.

Accepted 12 April 1991 behaviour toward their children's disease was child abuse within the range of Munchausen syndrome by proxy. ${ }^{8}$

Asthma is a chronic disease in childhood, the prognosis and evolution of which is dependent on correct management. Poor compliance with treatment among asthmatic children has been well documented and occurs in $10-50 \%$ of patients. ${ }^{9-13}$ We diagnosed some non-compliant families of asthmatic children as having Munchausen syndrome by proxy because the parents lied or concealed information when describing their child's symptoms, or treatment, or both, and because of the harmful impact this had on the child's mental and physical wellbeing.

\section{Patients and results}

We encountered 17 families (of 1648 asthmatic patients) whose management of asthma involved falsifying symptoms or manipulating treatment, or investigations, or both. In 10 cases this resulted in increased severity of the disease, and in seven in useless investigations and treatment being carried out. All these patients had been referred to us because their asthma was poorly controlled and all had previously consulted other departments of paediatric or respiratory diseases.

The 17 families that abused their children were divided into two groups depending on their attitude to treatment. Ten undertreated the children. There was a definite worsening of the children's asthma and as a result a need for attendance at the emergency department or hospital admission, invasive investigations, intensive care, and other aggressive medical treatment (table 1). Seven overtreated their children. There was no worsening of the child's asthma, but unnecessary investigations, admissions to hospital, and treatment were engineered by manipulating the medical system (table 2). After diagnosis in the hospital department originally consulted, all these families had repeatedly received correct medical information about the prognosis and management of asthma.

\section{FAMILIES THAT UNDERTREATED THEIR} CHILDREN

Ten families comprising 11 children were encountered within a three year period. The mean (SD) age of the children was $7.5(2.8)$ years, and there were two girls and nine boys. Ten of these 11 patients were described by their parents as severe asthmatics who had daily or weekly attacks. One patient was described as asthmatic, though he had type III recurrent alveolitis. All the families abused their children at some stage of management. 
Table 1 Families that undertreated children

\begin{tabular}{|c|c|c|c|c|c|c|c|}
\hline $\begin{array}{l}\text { Case } \\
\text { No }\end{array}$ & Sex & $\begin{array}{l}\text { Age } \\
\text { (years) }\end{array}$ & Perpetrator & Behaviour & $\begin{array}{l}\text { Child's medical } \\
\text { condition }\end{array}$ & Intervention & Result \\
\hline 1 & $\mathbf{F}$ & 8 & Parents & $\begin{array}{l}\text { No treatment, no medical } \\
\text { advice for four years } \\
\text { (weekly to daily attacks), } \\
\text { child was told she would } \\
\text { die suddenly }\end{array}$ & $\begin{array}{l}\text { Severe asthma (daily } \\
\text { attacks) }\end{array}$ & $\begin{array}{l}\text { Family therapy for parents, } \\
\text { intensive medical } \\
\text { treatment for child }\end{array}$ & Good \\
\hline 2 & $\mathbf{M}$ & 6 & Mother & $\begin{array}{l}\text { Acute and preventive } \\
\text { treatment not given } \\
\text { when necessary, wrong } \\
\text { treatment given }\end{array}$ & Severe asthma & Intensive treatment & $\begin{array}{r}\text { Death at } 17 \\
\text { years old }\end{array}$ \\
\hline 3 & $\mathbf{M}$ & 8 & Grandmother & $\begin{array}{l}\text { Acute treatment not given, } \\
\text { treatment given, } \\
\text { preventive treatment } \\
\text { not given }\end{array}$ & $\begin{array}{l}\text { Severe asthma and chronic } \\
\text { airway's obstruction }\end{array}$ & Joint consultation & Good \\
\hline 4 & $\mathbf{M}$ & 4 & Mother & $\begin{array}{l}\text { Acute treatment not given, } \\
\text { wrong treatment given, } \\
\text { preventive treatment } \\
\text { given, then stopped }\end{array}$ & $\begin{array}{l}\text { Frequent emergency } \\
\text { hospital admissions for } \\
\text { severe asthma or } \\
\text { bronchitis }\end{array}$ & Joint consultation & $\begin{array}{l}\text { Tried many } \\
\text { doctors }\end{array}$ \\
\hline 5 & $\mathbf{M}$ & 10 & Father & $\begin{array}{l}\text { Father forced him out of } \\
\text { emergency departinent } \\
\text { where he was treated for } \\
\text { an acute attack }\end{array}$ & $\begin{array}{l}\text { Immediate worsening, } \\
\text { and bad control of } \\
\text { asthma }\end{array}$ & Police called & No follow up \\
\hline 6 & $\mathbf{M}$ & 4 & Mother & $\begin{array}{l}\text { No acute treatment given, } \\
\text { no medical help } \\
\text { requested for severe } \\
\text { attacks }\end{array}$ & $\begin{array}{l}\text { Severe asthma, absent } \\
\text { from school }\end{array}$ & Joint consultation & Good \\
\hline $\begin{array}{l}7 \\
8\end{array}$ & $\stackrel{\mathbf{M}}{\mathbf{F}}$ & $\begin{array}{r}8 \\
12\end{array}$ & Mother & $\begin{array}{l}\text { No acute treatment when } \\
\text { necessary, wrong } \\
\text { treatment given, } \\
\text { preventive treatment } \\
\text { stopped, no medical } \\
\text { help requested when } \\
\text { necessary }\end{array}$ & $\begin{array}{l}\text { Severe asthma, poor school } \\
\text { attendance }\end{array}$ & $\begin{array}{l}\text { Joint consultation, work } \\
\text { with general pratitioner, } \\
\text { intensive education } \\
\text { programme }\end{array}$ & Good \\
\hline 9 & $\mathbf{M}$ & 6 & Mother & $\begin{array}{l}\text { Acute treatment not given, } \\
\text { wrong treatment given, } \\
\text { preventive treatment } \\
\text { stopped, no medical } \\
\text { help requested when } \\
\text { necessary }\end{array}$ & Severe asthma & $\begin{array}{l}\text { Joint consultation, work } \\
\text { with general } \\
\text { practitioner }\end{array}$ & Good \\
\hline 10 & $\mathbf{M}$ & 5 & Mother & $\begin{array}{l}\text { Acute treatment not given, } \\
\text { preventive treatment } \\
\text { stopped }\end{array}$ & $\begin{array}{l}\text { Severe asthma, absent } \\
\text { from school }\end{array}$ & Joint consultation & $\begin{array}{l}\text { Tried many } \\
\text { doctors }\end{array}$ \\
\hline 11 & $\mathbf{M}$ & 12 & Mother & $\begin{array}{l}\text { Actively exposed to } \\
\text { pigeons, although the } \\
\text { parents pretended all } \\
\text { the pigeons had been } \\
\text { given away }\end{array}$ & $\begin{array}{l}\text { Type III recurrent } \\
\text { alveolitis (pigeon } \\
\text { fancier's lung), } \\
\text { severe restrictive } \\
\text { airway's disease, absent } \\
\text { from school }\end{array}$ & Joint consultation & $\begin{array}{l}\text { Good medical } \\
\text { results }\end{array}$ \\
\hline
\end{tabular}

Table 2 Families that overtreated children

\begin{tabular}{|c|c|c|c|c|c|c|c|}
\hline $\begin{array}{l}\text { Case } \\
\text { No }\end{array}$ & Sex & $\begin{array}{l}\text { Age } \\
\text { (years) }\end{array}$ & Perpetrator & Behaviour & $\begin{array}{l}\text { Child's medical } \\
\text { condition }\end{array}$ & Intervention & Result \\
\hline 12 & $\mathbf{F}$ & 4 & Grandmother. & $\begin{array}{l}\text { Manipulated doctors to } \\
\text { obtain potent drugs } \\
\text { (antibiotics or } \\
\text { antiemetics) or invasive } \\
\text { investigations }\end{array}$ & $\begin{array}{l}\text { Mild asthma, a year's } \\
\text { treatment with } \\
\text { antibiotics and } \\
\text { antiemetic drugs, } \\
\text { invasive investigations }\end{array}$ & $\begin{array}{l}\text { Joint consultation, work } \\
\text { with general } \\
\text { practitioner }\end{array}$ & $\begin{array}{l}\text { Stable for } \\
\text { more than } \\
\text { two years, } \\
\text { tried many } \\
\text { doctors }\end{array}$ \\
\hline 13 & $\mathbf{F}$ & 11 & Mother & $\begin{array}{l}\text { Emergency hospital } \\
\text { admissions for invented } \\
\text { symptoms (fever, } \\
\text { cough, asthma), } \\
\text { obtained investigations } \\
\text { and treatment for no } \\
\text { reason }\end{array}$ & $\begin{array}{l}\text { Poor school attendance } \\
\text { and results, mild } \\
\text { asthma, unnecessary } \\
\text { hospital and treatment } \\
\text { admissions }\end{array}$ & Joint consultation & $\begin{array}{l}\text { Stable for } \\
\text { more than } \\
\text { a year, } \\
\text { tried many } \\
\text { doctors }\end{array}$ \\
\hline 14 & $\mathbf{F}$ & 10 & Mother & $\begin{array}{l}\text { Symptoms falsified, } \\
\text { common cold described } \\
\text { as asthma or bronchitis } \\
\text { to obtain prescriptions } \\
\text { for potent drugs and } \\
\text { invasive investigations }\end{array}$ & $\begin{array}{l}\text { Mild asthma, invasive } \\
\text { treatment and } \\
\text { restriction of sporting } \\
\text { activity }\end{array}$ & Joint consultation & $\begin{array}{l}\text { Good medical } \\
\text { progress }\end{array}$ \\
\hline 15 & $\mathbf{F}$ & 8 & Mother & $\begin{array}{l}\text { Mild symptoms presented } \\
\text { as severe asthma, } \\
\text { emergency admissions, } \\
\text { potent drugs given } \\
\text { (antibiotics or steroids) }\end{array}$ & $\begin{array}{l}\text { Mild asthma, invasive } \\
\text { treatments, absence } \\
\text { from school, no outdoor } \\
\text { activities, depression }\end{array}$ & Medical follow up & $\begin{array}{l}\text { Good } \\
\text { progress }\end{array}$ \\
\hline 16 & $\mathbf{M}$ & 7 & Mother & $\begin{array}{l}\text { Symptoms exaggerated, } \\
\text { considered by mother to } \\
\text { be mentally retarded } \\
\text { though normal, potent } \\
\text { drugs given }\end{array}$ & $\begin{array}{l}\text { Mild asthma, educational } \\
\text { retardation }\end{array}$ & Joint consultation & $\begin{array}{l}\text { Good } \\
\text { progress }\end{array}$ \\
\hline 17 & $\mathbf{M}$ & 6 & Mother & $\begin{array}{l}\text { Symptoms exaggerated, } \\
\text { manipulation of doctors } \\
\text { to obtain invasive } \\
\text { investigations including } \\
\text { blood tests and } x \text { ray } \\
\text { pictures }\end{array}$ & $\begin{array}{l}\text { Invasive investigations } \\
\text { and treatments, mild } \\
\text { asthma }\end{array}$ & $\begin{array}{l}\text { Joint consultation, work } \\
\text { with general practitioner }\end{array}$ & $\begin{array}{l}\text { Tried many } \\
\text { doctors }\end{array}$ \\
\hline 18 & $\mathbf{M}$ & 10 & Mother & $\begin{array}{l}\text { Manipulation of doctors to } \\
\text { obtain invasive } \\
\text { treatment: a year's course } \\
\text { of oral steroids for } \\
\text { stable, moderate asthma }\end{array}$ & $\begin{array}{l}\text { Weight gain, growth } \\
\text { retardation, moderate } \\
\text { asthma }\end{array}$ & Joint consultation & $\begin{array}{l}\text { No treatment } \\
\text { with } \\
\text { steroids, } \\
\text { stable } \\
\text { moderate } \\
\text { asthma }\end{array}$ \\
\hline
\end{tabular}


Treatment during the acute attack

In seven of the 10 families the prescribed treatment was not given to the child during an attack. In six of them a large number of ineffective treatments were used such as a ventilator (blowing dust), nebulisation of distilled water, aspirin, cold syrups, very small doses of bronchodilator syrups, and cold packs on the chest, all to no effect. None of these families spontaneously mentioned their behaviour. All seven children had severe asthma; one died at the age of 17 during his fifth episode of status asthmaticus, three had chronic airway's obstruction, and five had frequent emergency treatment or admission to hospital.

\section{Preventive treatment}

In five of the seven families who did not give the correct treatment during the acute attack, the preventive treatment was also not given to the child, although the parents pretended that it was. The following drugs were withheld: beclomethasone $(n=3)$, salbutamol $(n=4)$, and sustained release theophylline $(n=5)$. To ascertain that preventive treatment had effectively been withheld we interviewed the children about the first two drugs, and then measured the theophylline concentration in the blood. The children were asked in front of the parents to write down, or draw, what they received as daily treatment. The parents were then asked about the missing drugs. Monitoring theophylline concentrations in the blood was useful for the five patients concerned, and on several occasions showed that none had been given.

Seven of the $\mathbf{1 0}$ families said they had been avoiding known allergens when they had not. In one case a 10 year old boy had had three acute episodes of type III alveolitis (pigeon fancier's lung). He had developed severe symptoms of weight loss $(6 \mathrm{~kg})$, high fever, and dyspnoea, and had spent a long time in hospital before he recovered. The parents, who owned some $\mathbf{4 0}$ pigeons that lived in their home, had been informed on several occasions about the aetiology of their son's disease. They had stated that all their birds had been given away, when all the time they were hiding the 40 pigeons in the room next to the patient's room, and this was only discovered when the hospital social worker was sent to visit the house after the third acute attack.

\section{Withholding of treatment}

In one case no treatment at all was given and no medical advice was sought for a period of four years for a child who was having daily or weekly attacks. She was openly told by her family that she was at high risk of sudden death (table 1). She developed severe asthma and had two episodes of status asthmaticus.

Another patient was forced out of the emergency department by his father while he was being treated with oxygen and nebulised salbutamol for an acute attack. It was necessary to ask the help of the police to get the child into the emergency department at another hospital.
Family history

The family histories showed that at least one parent in each family had had a chronic medical problem during their own childhood. The most common was asthma (eight mothers, two fathers, and one grandmother). Siblings were affected in half the families. In addition, six of the 10 mothers were clinically depressed, the parents had recently divorced in three families, a close relative had died in one, and the mother of another child was known to abuse morphine.

\section{Family behaviour with doctors ${ }^{3}$}

Two of the 10 families were always seeking medical advice. Five of the families refused to allow doctors to see their children; these are the families that we consider to be at high risk, because they do not attend follow up appointments, do not call a doctor if the child has frequent attacks, and nevertheless are always seeking different treatments. The remaining three families disliked doctors and threatened them.

FAMILIES THAT OVERTREATED THEIR CHILDREN During the three year period we encountered seven families who abused their children; there were four girls and three boys, with a mean (SD) age of $8(2.5)$ years. These families behaved as if they wanted their children to remain chronically ill. The respiratory consequences were not as severe as those found in the undertreated children, but there was health abuse that directly affected school attendance and the child's psychosocial development as well as subjecting the child to unnecessary, expensive, and potentially harmful investigations and treatments.

\section{Family behaviour}

All these families exaggerated their descriptions of the child's symptoms-for example, a mild symptom like a non-productive cough was described as acute asthma. Some parents deliberately falsified the symptoms, mentioning high fever, vomiting, and dyspnoea, that had never occurred. All seven families were used to manipulating the medical system to obtain prescriptions for potent drugs like antibiotics, antiemetics, bronchodilators, and oral corticosteroids. In four of the seven families the strategy was to call the general practitioner on duty (who did not know the patient) and tell him that the child was being treated for severe asthma, and had to receive antibiotics, antiemetics, oral corticosteroids, or bronchodilators as soon as he began to cough. Three of the families used to present the child in the emergency department of two or more hospitals with exaggerated or invented symptoms.

Five of the patients underwent useless and potentially harmful investigations such as blood tests, skin tests, and $x$ ray examinations on several occasions. Six of the families overused medication-for example, giving oral corticosteroids or antibiotics for a common cold.

Family history

The family histories showed that six of the 
mothers and one of the grandmothers had had asthma as children. Five of the seven mothers were clinically depressed, and the grandparents of one child had recently died. One mother was a single parent living with her own parents. Five families were always seeking medical advice, one family would not allow a doctor to see the child, and one family disliked and threatened doctors.

\section{Discussion}

In all 17 cases there was evidence that the parental mismanagement of the child's asthma constituted child abuse. In the families that undertreated their children the abuse consisted of providing no relief to the child during an attack, although they knew how to stop it. An attack of asthma is harmful to a child, both physically and mentally. The abuse by the families that overtreated their children consisted of imposing potentially harmful and useless investigations or treatments, or both, on the child by fabricating or exaggerating the disease.

In the first group the persistent severity of the symptoms, which remained unresponsive to the (supposed) treatment, led to the diagnosis of severe asthma. It can be assumed that most of these patients would have reacted differently with correct management. Severe asthma was the fabricated illness, although these children may have had mild or moderate disease. In the second group the disease was factitious; the symptoms described by the parents never existed. Indeed, the illness was made to seem more real to the parents by the invasive investigations and treatments imposed on the child. The severity of the asthma was factitious, but the children really had mild asthma.

Most of the parental behaviour concerning asthma management can be described as neglect. In the 10 families that undertreated children, eight mothers did not treat the attacks at all, and two parents refused necessary medical care. Five mothers also withheld the preventive treatment. The disease was actively induced in cases where parents used ineffective treatments (with a direct worsening of the attack) or provided active contact with the allergen. In the seven families that overtreated their children, the parent's behaviour consisted of actively inducing the useless investigations and treatments. These cases of parental mismanagement of childhood asthma illustrate a parenting disorder. There was a disturbed psychosocial background in all 17 families.

Pathogenic hypotheses have been proposed by several authors. When describing the illness of the child, the mother (or grandmother) receives much attention and respect from the medical world and from her own surroundings. This need for medical attention can lead to so called 'doctor addiction'. ${ }^{2}$ Through the illness the parent can also maintain a symbiotic relationship with the child, ${ }^{14}$ which may explain why the syndrome is often diagnosed in young families in which children are beginning to develop their own personalities. Abuse can also occur in cases of marital conflict. The continuous illness of the child diverts attention from the marital conflict-for example, the two parents are reunited in their common care for the sick child. ${ }^{1}$

The care and devotion that the abusing parent gives to the sick child often wins for that parent the love that was lacking in their own early childhood. Recent research has shown that exploitative dominance of a submissive child by a parent does occur. ${ }^{15}$ Most of the parents that abused their children were themselves abused as children. The mothers often tried more direct ways of expressing their own distress before abusing their children, including complaining of depression and psychosomatic symptoms or suicidal thoughts, or by overusing drugs themselves. 57

All these patterns have been associated with other psychosocial disturbances. The specific precipitating factors that lead to Munchausen syndrome by proxy in these disturbed families were physical vulnerability (bronchial hyperactivity or allergy), the relationship between the family and the doctor, and the unwilling collaboration of the medical system.

\section{Conclusions}

Parents' management of asthma as a chronic physical disease in a child may develop into Munchausen syndrome by proxy. In three years of joint consultations about 1648 patients with asthma we found management of asthma that constituted child abuse in some $1 \%$ of asthmatic patients and their families. Early recognition of behaviour that falls within the accepted range of the syndrome may prevent medical professionals from becoming unwilling collaborators in abuse. Munchausen syndrome by proxy should be considered as a differential diagnosis in severe asthma, or if stable moderate asthma suddenly becomes worse.

Checking compliance of both parents and patients should be regarded as an essential part of a doctor's duty if child abuse is to be recognised and the child's health protected.

1 Meadow R. Munchausen syndrome by proxy. The hinterland of child abuse. Lancet 1977;ii:343-5.

2 Meadow R. Munchausen syndrome by proxy. Arch Dis Child 1982;57:92-8.

3 Zitelli BJ, Seltman MF, Shannon RM. Munchausen's syndrome by proxy and its professional participants. $A m \mathcal{F} D$ is Child 1987;141:1099-102.

4 Kaufman KL, Coury D. Munchausen syndrome by proxy: a survey of professionals' knowledge. Child Abuse Negl 1989;13:141-7.

5 Rosenberg DA. Web of deceit: a literature review of Munchausen syndrome by proxy. Child Abuse Neg 1987; 11:547-63.

6 Warner JO, Hathaway MJ. Allergic form of Meadow's syndrome (Munchausen by proxy). Arch Dis Child 1984;59: syndrome.

7 Libow JA, Schreier H. Three forms of factitious illness in children: when is it Munchausen syndrome by proxy? Am children: when is it Munchausen sy

8 Godding V, Kruth M, Gallet D. Approche multidisciplinaire en co-consultation (pédiatr-pédopsychiatre/psychologue) pour enfants et adolescents asthmatiques et leurs familles. Neuropsychiatrie de lenfance 1989;37:385-94.

9 Spector S, Kinsman R, Mawhinney $\mathrm{H}$, et al. Compliance of patients with asthma with an experimental aerosolized medication: implications for controlled clinical trials. f Allergy Clin Immunol 1986;77:65-70.

10 Spector S, Lewis C. Compliance factors. F Allergy Clin Immunol 1986;78:529-33.

11 Moran MG. Treatment non-compliance in asthmatic patients: an examination of the concept and a review of the literature. Seminars in Respiratory Medicine 1987;8:271-7. 
12 Sbarbaro JA. Strategies to improve compliance with therapy. Am $\mathcal{F}$ Med 1985;79:34-7.

13 Voyles J, Menendez $\mathbf{R}$. Role of patient compliance in the management of asthma. $\mathcal{J}$ Asthma 1983;20:411-18.

14 Guandolo VL. Munchausen syndrome by proxy. An out patient challenge. Pediatrics 1985;75:526-30.

$15 \mathrm{Griffith} \mathrm{JL}$. The family systems of Munchausen syndrome by proxy. Fam Process 1988;27:423-7.

\section{Commentary}

The term Munchausen syndrome by proxy was used initially as a headline to highlight underrecognised forms of child abuse. That journalistic licence has been justified by the discovery of many children being subjected to suffocation, poisoning, and other extreme physical abuse. The term has also permitted child care workers and legislators to intervene more easily under the cover of Munchausen syndrome by proxy in some serious complex cases of emotional abuse in which mothers were not physically harming their children but were ruining their lives with stories of false illnesses.

The term, and particularly its overuse, has led to problems (at times I have regretted coining it). Many lawyers, social workers, and sometimes doctors, seem to regard Munchausen syndrome by proxy as an identifiable disorder that afflicts certain women; it is common for the perpetrator to announce proudly 'I've got Munchausen syndrome by proxy, and the judge says I needn't go to prison providing I see the specialist and have treatment.'

A more worrying issue for the paediatrician is how readily factitious illness should be identified, and how readily child abuse procedures should be invoked. Most of us use our illnesses to our own advantage to gain sympathy, freedom from unpleasant tasks, and some material benefits (if only some self indulgence). Chronic illness, with all its burdens, also bring benefits: certain allowances and privileges. Similarly, mothers will use illness to their own advantage, and because illness may bring both emotional and material advantage to that mother she will occasionally exaggerate the illness and deceive or act in ways that are mildly harmful to the child for her own advantage.

Just as familiar to paediatricians are the many mothers who, because of their own anxieties and uncertainties, perceive symptoms in their child that others cannot observe. Though the stories of illness that they relate to the paediatrician may cause needless investigation and unpleasantness for the child, it would be rare to classify such a mother's behaviour as child abuse.

Godding and Kruth claim that they have identified 17 families displaying behaviour of Munchausen by proxy within a large clinic serving nearly 2500 families. They do not define their terms precisely, and in particular their cases do not have the hallmark of Munchausen syndrome by proxy-that the child, when away from the parents, is better. Readers may feel that the authors are wrong to classify the 17 cases in this way. Some are non-compliers. Yet paediatricians are aware that common reasons for undertreatment and non-compliance are our failure to spend enough time with our patients or to adapt and present our management strategies in a way that is acceptable and appropriate to the families' beliefs and culture. At other times we may be inappropriately optimistic in our expectation for families to comply with demanding and frequent treatments-for example, requesting that a mother who relies on 20 cigarettes a day should stop smoking altogether. In a clinic in which more than 2000 children with asthma are seen I would expect most to be non-compliant to some extent. Similarly a large proportion will exaggerate symptoms or overuse treatment for other reasons. Such behaviour is normal.

It is noteworthy that the authors identify only 17 children, and it is because of that - and my knowledge of their work-that I believe that they are probably right to apply the label Munchausen syndrome by proxy to that small minority of their patients. These seem to be extreme cases in which the parental actions are severely interfering with the child's healthy development. They are not merely those cases by which we are irritated: the parents who demand a free telephone because of their child's extreme breathlessness and blue spells (which only the mother sees); the family whose child always has a normal peak flow at the clinic yet who has, because of the child's asthma, a 'disabled' car parking badge that enables them not only to park outside Marks and Spencer buteven more annoyingly-within the hospital grounds (while the doctor seeing them gets his car's wheels clamped).

In any chronic childhood illness there will be a small minority of parents whose behaviour, in terms of compliance and non-compliance, amounts to child abuse. I believe it is correct to be prepared in these extreme cases, when expert help and persuasion has failed, to confront the issue as one of child abuse and to invoke child protection measures including, if necessary, resort to the courts.

As with all child abuse it is important to stand back and work out just how much the parents' actions are jeopardising the child's present happiness and future health and development, and to consider carefully the consequences of intervention.

$S$ R MEADOW

Department of Paediatrics and Child Health, St James's University Hospital, 